Should the Mental Health Commission decide that point 2 above is not good practice and that guardianship does not convey the right to enforce medical treatment against the patient's wishes, they should recommend that the Mental Health Act 1983 is amended to provide for compulsory community care, including medicines for the small group of psychiatric patients who may be maintained in the community on medicines, but relapse if they discontinue them and refuse to take the treatment on an informal basis.

REFERENCES

'Rohde, P. D. (1983) Mental Health Act Commission and the Code of Practice. British Medical Journal, 287, 1318.

'Sinclair, L. (1984) Mental Health Act and the Code of Practice (letter). British Medical Journal, 288, 149.

${ }^{3}$ Home Ofpice and Department of Health and Social SECURTY (1975) Report of the Committee on Mentally Abnormal Offenders (the Butler Report). Cmnd 6244. London: HMSO.

‘Gostin, L. O. (1977) A Human Condition, Vol II. London: National Association of Mental Health.

sEdwards, A. H. (1975) Mental Health Service, 4th edition. London: Shaw.

'Department of Health and Social Security (1976) A Review of the Mental Health Act 1959. London: HMSO.

'_ (1978) Review of the Mental Health Act 1959. Cmnd 7320. London: HMSO.

'LePF, J. P. \& WiNG, J. K. (1971) Trial of maintenance therapy in schizophrenia. British Medical Journal, iii, 599.

'HiRsCh, S. R. et al. (1973) Out-patient maintenance of chronic schizophrenic patients with long-acting fluphenazine. British Medical Journal, $i, 633-37$.
Note 1

The Memorandum to the Mental Health Act 1983: The Memorandum (paragraph 2) says that it is for the guidance of all those who would be working with the Act. It goes on to say 'it cannot provide an authoritative interpretation of the law or override the statutory provisions of the Act or regulations nor does it describe every detail of the Act.' Apart from this disclaimer, which makes it clear that ultimately we must go back to the words of the Act itself, the Memorandum is also not infallible as far as wording is concerned. A curious but important example of this concerns the grounds for detention under Sections 2 3, 4 and 5. In each case the Act refers to "his own health or safety or with a view to the protection of others'-the exact wording in connection with others varies slightly between the Sections. The Memorandum, however, in paragraphs 18 and 19 correctly refers to "health or safety' but in paragraphs 26 and 33, refers to 'health and safety', a small but very significant error.

\section{Note II}

In my experience patients who have major mental illness, but refuse treatment, commonly change their mind and get involved with the rehabilitation programme after they have been given medicine compulsorily for a time. The opposite however does not apply. The major sanction would be either a forcible injection, or return to hospital. In practice return to hospital is the appropriate sanction and has worked well with the present trial leave. However, for patients subject to guardianship it would have the disadvantage of having to use compulsion against a relatively symptom-free but noncomplying patient. This could be justified on the basis that the order was being used to prevent deterioration, but to ensure that this was done, the Commission would need to spell out that it was good practice to do so.

\section{Second College ECT Survey}

The Research Committee of the College plans to carry out a second survey in 1985-this will be five years after the first. Dr John Pippard and Les Ellam's Report Electroconvulsive Therapy in Great Britain, 1980 came to some worrying conclusions and the authors subsequently made some specific recommendations about how practice might be improved. The object of the second survey would be to determine to what extent these recommendations have influenced practice.

We are at present in the process of applying for funding to the DHSS for the project. If the application is successful we would hope to appoint a senior consultant psychiatrist, for a period of two years, to undertake the survey. It is likely that the survey would be based in London. The post cannot be formally advertised until the project is funded, but the Committee would like to hear from any member of the College who might be interested in such a post.

C. P. Freeman

Secretary, Research Committee

\section{Prevention of Psychiatric Morbidity}

The Section for Social and Community Psychiatry has set up a Working Party to consider the role of prevention in the field of morbidity. The Section for Child and Adolescent Psychiatry have nominated a representative, and the Director of the Health Education Council and Professor J. Morris have been invited to join. At its first meeting held on 14 June, it was agreed to write to all Sections and to invite contributions from individual Members and Fellows. If you have any points that you wish the Working Party to consider, please let me know. We would be particularly interested in hearing of any research in progress or service developments in the field of prevention. The Health Education Council have offered to fund a literature search and we may be looking for a suitably qualified individual to carry out this work (possibly at Senior Registrar level).

A. C. Brown

Convener 